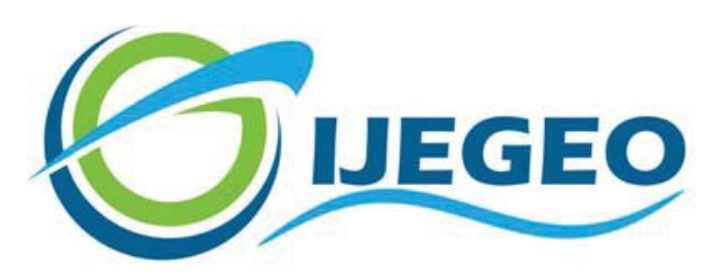

International Journal of Environment and Geoinformatics (IJEGEO) is an international, multidisciplinary, peer reviewed, open access journal.

\title{
Mobile Technology-Based Participatory Mapping to identify Home Industries in Pekalongan City- Indonesia
}

\author{
Akhmad Arifin HADI, Setyardi Pratika MULYA, \\ M. Rahmad SUHARTANTO, Herdhata AUGUSTA
}

\author{
Chief in Editor \\ Prof. Dr. Cem Gazioğlu \\ Co-Editors Prof. Dr. Dursun Zafer Şeker, Prof. Dr. Şinasi Kaya, \\ Prof. Dr. Ayşegül Tanık and Assist. Prof. Dr. Volkan Demir
}

Editorial Committee (June 2022)

Assoc. Prof. Dr. Abdullah Aksu (TR), Assoc. Prof. Dr. Uğur Algancı (TR), Assoc. Prof. Dr. Aslı Aslan (US), Prof. Dr. Levent Bat (TR), Prof. Dr. Paul Bates (UK), İrşad Bayırhan (TR), Prof. Dr. Bülent

Bayram (TR), Prof. Dr. Luis M. Botana (ES), Prof. Dr. Nuray Çağlar (TR), Prof. Dr. Sukanta Dash (IN), Dr. Soofia T.

Elias (UK), Prof. Dr. A. Evren Erginal (TR), Assoc. Prof. Dr. Cüneyt Erenoğlu (TR), Dr. Dieter Fritsch (DE), Prof.

Dr. Ç; Prof. Dr. Manik Kalubarme (IN), Dr. Hakan Kaya (TR), Assist. Prof. Dr. Serkan Kükrer (TR), Assoc. Prof. Dr.

Maged Marghany (MY); Prof. Dr. Micheal Meadows (ZA), Prof. Dr. Nebiye Musaoğlu (TR), Prof. Dr. Masafumi

Nakagawa (JP), Prof. Dr. Hasan Özdemir (TR), Prof. Dr. Chyssy Potsiou (GR), Prof. Dr. Erol Sarı (TR), Prof. Dr. Maria Paradiso (IT), Prof. Dr. Petros Patias (GR), Prof. Dr. Elif Sertel (TR), Prof. Dr. Nüket Sivri (TR), Prof. Dr. Füsun

Balık Şanlı (TR), Dr. Duygu Ülker (TR), Prof. Dr. Seyfettin Tsaş (TR), Assoc. Prof. Dr. Ömer Suat Taşkın (TR), Assist. Prof. Dr. Tuba Ünsal (TR), Assist. Prof. Dr. Sibel Zeki (TR) 


\title{
Mobile Technology-Based Participatory Mapping to identify Home Industries in Pekalongan City- Indonesia
}

\author{
Akhmad Arifin Hadi ${ }^{1, *}$ iD, Setyardi Pratika Mulya ${ }^{2}$ iD, M. Rahmad Suhartanto, iD \\ Herdhata Augusta ${ }^{3}$ iD
}

${ }^{1}$ Department of Landscape Architecture, Faculty of Agriculture, IPB University (Bogor Agricultural University), Bogor, Indonesia

${ }^{2}$ Department of Soil Science and Land Resource, Faculty of Agriculture, IPB University (Bogor Agricultural University), Bogor, Indonesia

${ }^{3}$ Department of Agronomy and Horticulture, Faculty of Agriculture, IPB University (Bogor Agricultural University), Bogor, Indonesia

* Corresponding author: Akhmad Arifin Hadi

Received 07.10.2021

E-mail: arifin_hadi@apps.ipb.ac.id Accepted 02.01.2022

How to cite: Hadi et al., (2022). Mobile Technology-Based Participatory Mapping to identify Home Industries in Pekalongan City-

Indonesia, Journal of Environment and Geoinformatics (IJEGEO), 9(2):161-168. doi. 10.30897/ijegeo.1012740

\begin{abstract}
Participatory mapping is a method to geolocate city elements and places involving local people as data collectors. At present, adequate technology for participatory mapping is available, i.e., smartphones, GPS, and the internet. Based on various literature, it is an effective method for obtaining spatial information from individuals. Therefore, in this research, a mobile technology-based participatory mapping method was implemented to identify the home industry's Geolocation as an essential element of Pekalongan city's economy. This research involved Bogor Agricultural University (IPB) students who did Thematic field practice (KKNT) in Pekalongan City. Students were requested to walk and Geolocate the home industries of 6 villages using the Locus Map application. The data collected were transferred to the researcher online to be analyzed the geo-location and concentration of the home industries using Kernell Density analysis in ArcGIS software. The result shows that there are 35 home industries identified on mostly settlements land use and more concentrated in Kuripan Kertoharjo Village. This information is helpful for urban planners to manage settlements where home industries exist. The involvement of students as on-site surveyors was an advantage due to the familiarity with mobile technology.
\end{abstract}

Keywords: participatory, mapping, industrial revolution 4.0, Locus Map, GPS, Geolocation

\section{Introduction}

The availability of detailed spatial information related to the home industry's Geolocation is essential for urban planning decision-making. However, the formal data of geolocation of the home industry is rarely provided in legal data (Tata and Eteje, 2022). The rare spatial data such as geolocation of home industries is needed in comprehensive urban planning (Endarwati, 2011). The data of geolocation of home industries can be collected by participatory mapping using GPS mobile and GIS. Participatory mapping can be used for land use planning/zoning (Brown et al., 2018), regional potential identification (Pelly and Wiyono, 2020) and disaster mapping/mitigation (Klonner et al., 2021).

Online participatory mapping is a method to record city elements that involves people or the public as an on-site data collector. Online Participatory Mapping is possible to be implemented today and increase the level of public knowledge and understanding about mapping (Kingston, 2007). There are well-known method of participatory mapping such as Web-based participatory mapping, Participatory GIS (PGIS), public participation GIS (PPGIS), Volunteered Geographic-Information (VGI) (Brown et al., 2018) and Mobile Technology BasedParticipatory Mapping (Fornace et al., 2018). Those method utilize internet, GPS and mobile technology which is developed to have a wider range of features and functions, and integrated with desktop and/or web GIS software that can be used to collect various geometric data (points, polylines, polygons) and generate attribute data formats that are widely used (Nowak et al., 2020).

The GPS is an essential tool in the personal smartphone to detect human activities (Zhou and Li, 2018). People can record actual geolocation data of particular objects on-site by using GPS integrated smartphone technology. The GPS mobile data in smartphones can be shared online between data collector and researcher. The possibility to share data online between GPS mobile ease the researcher to collect data from on-site data collector that usually take time and cost in conventional survey method. The location identification, data capture, and monitoring can be obtained by using mobile technology (Lee, 2020). The other advantage of using online method for collecting data is that planners can identify important public facilities' spatial information (Falco et al., 2019). Currently, GPS-based applications are widely available, easy to use and inexpensive so that field data collection is easier to carry out (Azyat et al., 2012). The data collected from GPS mobile of data collectors were analyzed by using GIS (Gülmez and Tujat, 2017; Arca et al., 2018; Korkutan et al., 2018). GIS is an appropriate tool to process data related to location and produce outputs useful for proper judgments based on knowledge 
of that impact (Thrall, 1998). Along with the rapid development of internet technology, GIS mapping using the internet connection and mobile technology can be carried out by connected people through online networks. Mobile technology has contributed to the efficiency of space and time for traditional planning activities. Mobile devices support users to engage in planning activities anywhere, anytime without any restrictions space and time (Riggs and Gordon, 2017). In internet GIS technology, humans who operate smartphones can participate as sensors to collect information about their location and share that information with those who need (Laituri and Kodrich, 2008). GIS methods using smartphones offer opportunities for gathering up-to-date spatial information for adaptive planning and management (Korpilo et al., 2017).

However, public participation in participatory mapping is still in a debate because, in some cases, the quality of the data collected from participator was low (Flanagin and Metzger, 2008; Rzeszewski and Kotus, 2019). Despite this weakness, the web-based participatory method can be an option to obtain actual data on-site effectively. In this method, the internet plays an important tool to get feedback from people (Kelly et al., 2012).

The development of cities in Indonesia is overgrowing and changing rapidly. Online Participatory mapping is possible to be an efficient method to obtain detailed spatial data of city elements in Indonesia. The knowledge of the spatial location of important objects and places is still rarely found in proper form. The spatial data are mainly consisting of primary data but not information about specific areas of features. It is a very long work and earns a high budget to obtain detailed information about places in a city using conventional method.

Pekalongan city is an excellent example of a case study because there are many home industries. Pekalongan City is a famous city as the center of the batik industry (Rukayah et al., 2015), developing as a home industry since the early 20th century. Batik industry is a traditional fabric in Indonesia that supported by home industries. Pekalongan city is currently developing as a batik-based creative tourism area and was designated by UNESCO as one of the world's creative cities in 2010 (Damayanti and Latifah, 2015). However, the geolocation of home industries in Pekalongan city was not provided in formal data but it usually together with polygon data of settlements. On the other hand, the spatial data of home industries is need to be considered in city development to conserve the Batik culture. Therefore, the geolocation of Batik home industries' is essential to be identified as input for city planning of Pekalongan city. In this research, we tried to implement Mobile Technology Based-Participatory Mapping using Locus Map application in smartphones to record Geolocation of home industries in Pekalongan city.

\section{Materials and Methods}

The research was conducted in Pekalongan city under IPB University program called as Kuliah Kerja Nyata (KKNT). KKNT is a thematic practice program for public services carried out by IPB in various cities in Indonesia, including Pekalongan City. IPB and the Pekalongan city have collaborated in the implementation of KKNT since 2015. In 2019, KKNT was held in 6 villages including Setono, Gamer, Kalibaros, Sokoduwet, Kurert Kertoharjo, and Kuripan Yosorejo. The KKNT activity was attended by 42 students from various departments and faculties at IPB divided into seven students for each village. They lived in designated villages from June 17 th to July 25th, 2019, to do public services, including online participatory mapping. The KKNT students in this study were on-site surveyors to geolocate city elements of each designated village.

The research method was participatory mapping by

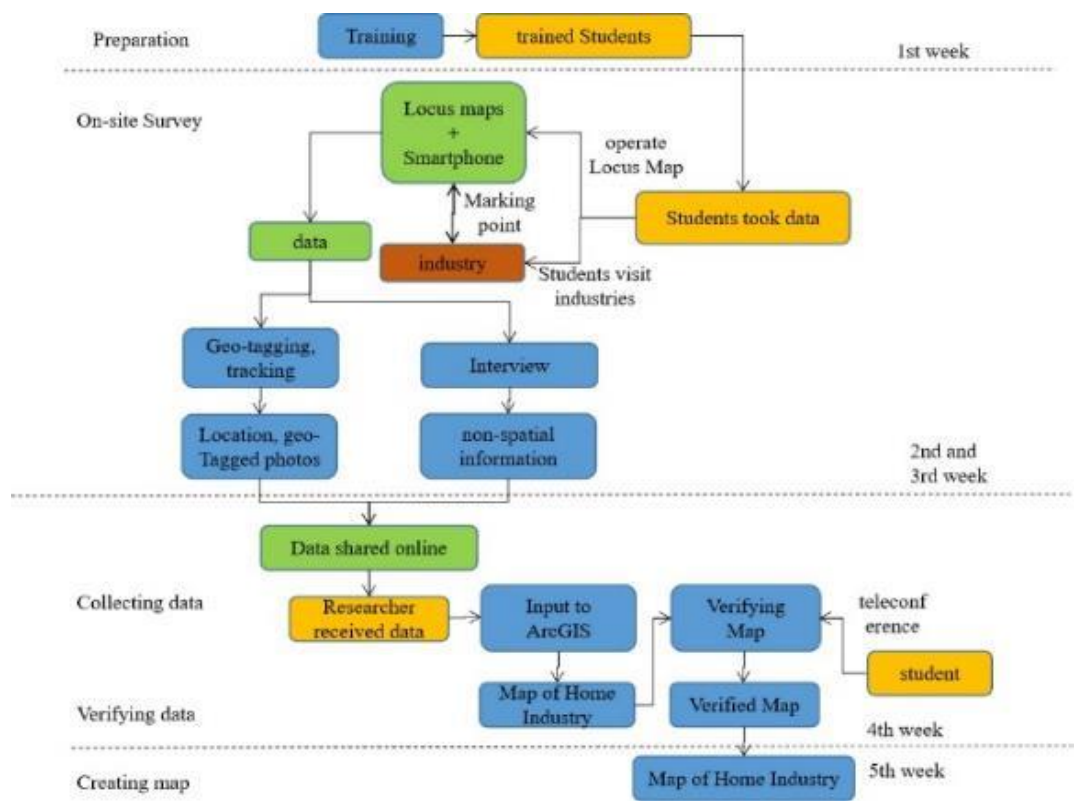

Fig. 1. The flow of research 
using participants' mobile phones or smartphones (Figure 1). The Locus Map application is the primary tool for recording the Geolocation of investigated objects installed in each participant's smartphone. Each participant must have a smartphone installed with the Locus Map application. The smartphone must be in a fully charged battery capacity and with sufficient memory capacity when the participant conducts a field survey.

Participants were asked to take a walk in the village that has been determined. When they see the home industry, participants open the Locus Map application, then mark the city element's location and fill in information about the name and a brief description of the identified item, such as name, owner, and products on the Locus Map application. The recorded data were then saved in the participant's smartphone and then transferred to the researcher's Google Drive.

Locus Map is a multi-functional Android navigation app adding advanced online and offline GPS capabilities to Android devices. Based on the answers to our questions to the locus map, it is stated that the level of accuracy of the geolocation shown by the Locus Map application depends on the type of user's smartphone. Regardless of the variety of participant smartphone types, Zandbergen and Barbeau (2011) mentions that the error from the GPS of the mobile phone ranges from 5.0 to 8.5 meters. (Gabryszuk, 2020) mentioned that the mean standard deviations of determinations of horizontal coordinates performed by mobile phone were in the range from 1.27 to $2.93 \mathrm{~m}$ for the Iphone and from 2.84 to $5.04 \mathrm{~m}$ for the Android smartphones.

There are three types of data collected from participants: geolocation points, names and descriptions of points, and photos (Figure 2). The geolocation points, titles, and descriptions were together in the GPX file, while the photos were supplementary of point data and available in separate files. Unfortunately, not all geolocation point data is equipped with photos because participants do not always take photos when determining location points. The data of GPX files and photos taken from each participant were then delivered online from the Locus Map of each participant to the researcher's Google Drive.

The GPX data were then imported to ArcGIS as point features. The geolocation points consist of datasets such as identity number, time, coordinate, elevation, name, and descriptions in the ArcGIS. Each point was joined with formal spatial data from Pekalongan city, such as administrative areas and existing land use, to identify the distribution of geolocation point features based on administrative areas and confirm each point if suitable with the land use information. The data used were home industries data, including Geolocation and description. This study's category of home industries is any industrial activity that processes raw materials or semi-finished materials into finished materials carried out at home. Therefore, the home industry's point is the point of the industry located in the land use of settlements and other non-industrial land use.

\section{Results}

Students who were participants in this study installed and operated Locus Map application and marked geolocation of important places on designated villages. The data recorded in the Locus Map includes geolocation point data, name of points, elevation, the direction of GPS of smartphones, the coordinate of each point, descriptions elements, elevations, time, photos, etc (Figure 2). The GPX file data were then exported from the Participants' Locus Map application to the Researcher's PC by Google Drive and e-mail. The data
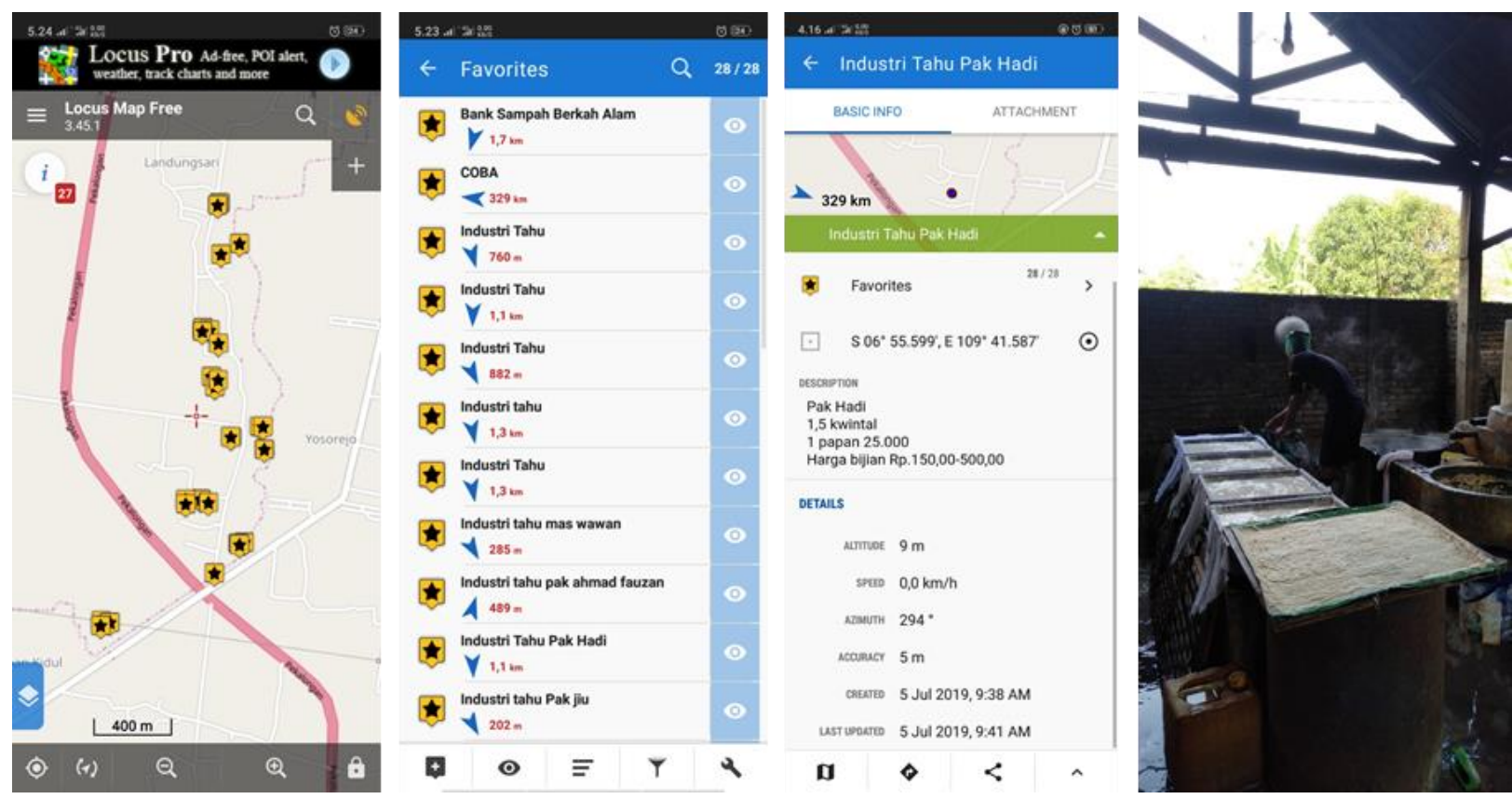

ig. 2. The display of data on the Locus Map Application, from left to right: geolocation points data, name of oints and elevations, description of points and coordinate, an example of a photo of home industry 


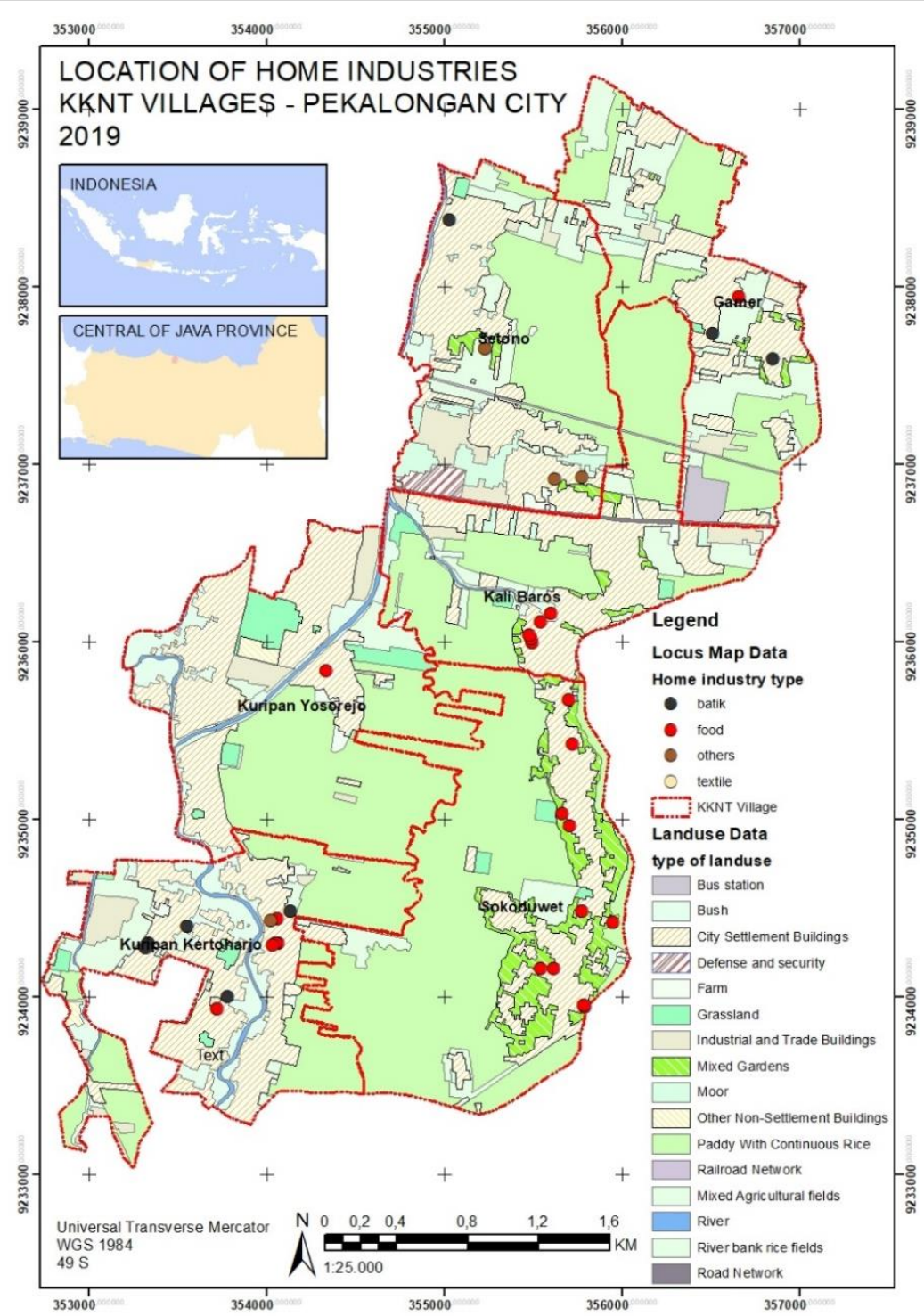

Fig. 3. Locations of Home Industries on 6 villages

received from Participants were then analyzed by using ArcGIS. The participants recorded 109 geolocations of essential elements of 6 villages, including paddy fields, cultural area, industries, infrastructures, market and shops, garden and parks, public facilities, governmental office, boarding house, and nature. From a total of 109 data obtained from participants, only 35 data of home industries were then taken for the analysis. The geolocation points of home industries were only the points that fall in the non-industrial area. (Figure 3 and Table 1). The home industries were mostly food industries (22 points), batik industries ( 8 points), textile industries (1 point), and other industries (4 points). According to the village area, the home industries were more found on Kuripan Kertoharjo village (11 points), followed by Sokoduwet village (10 points), Setono village (5 points), Kalibaros village (5 points), Gamer village (3 points), and Kuripan Yosorejo village (1

Table 1. Home Industries on six villages

\begin{tabular}{lllllll} 
& \multicolumn{2}{l}{ Type of Home Industry } & & & Total \\
\cline { 2 - 6 } Name of Village & Food & Batik & textile & Others & & 5 \\
\hline Setono & - & 1 & 1 & 3 & - & 3 \\
\hline Gamer & 1 & 2 & - & - & 5 \\
\hline Kalibaros & 5 & - & - & 1 & 11 \\
\hline Kuripan Kertoharjo & 5 & 5 & - & - & 1 \\
\hline Kuripan Yosorejo & 1 & - & - & - & 10 \\
\hline Sokoduwet & 10 & - & 1 & 4 & 35
\end{tabular}




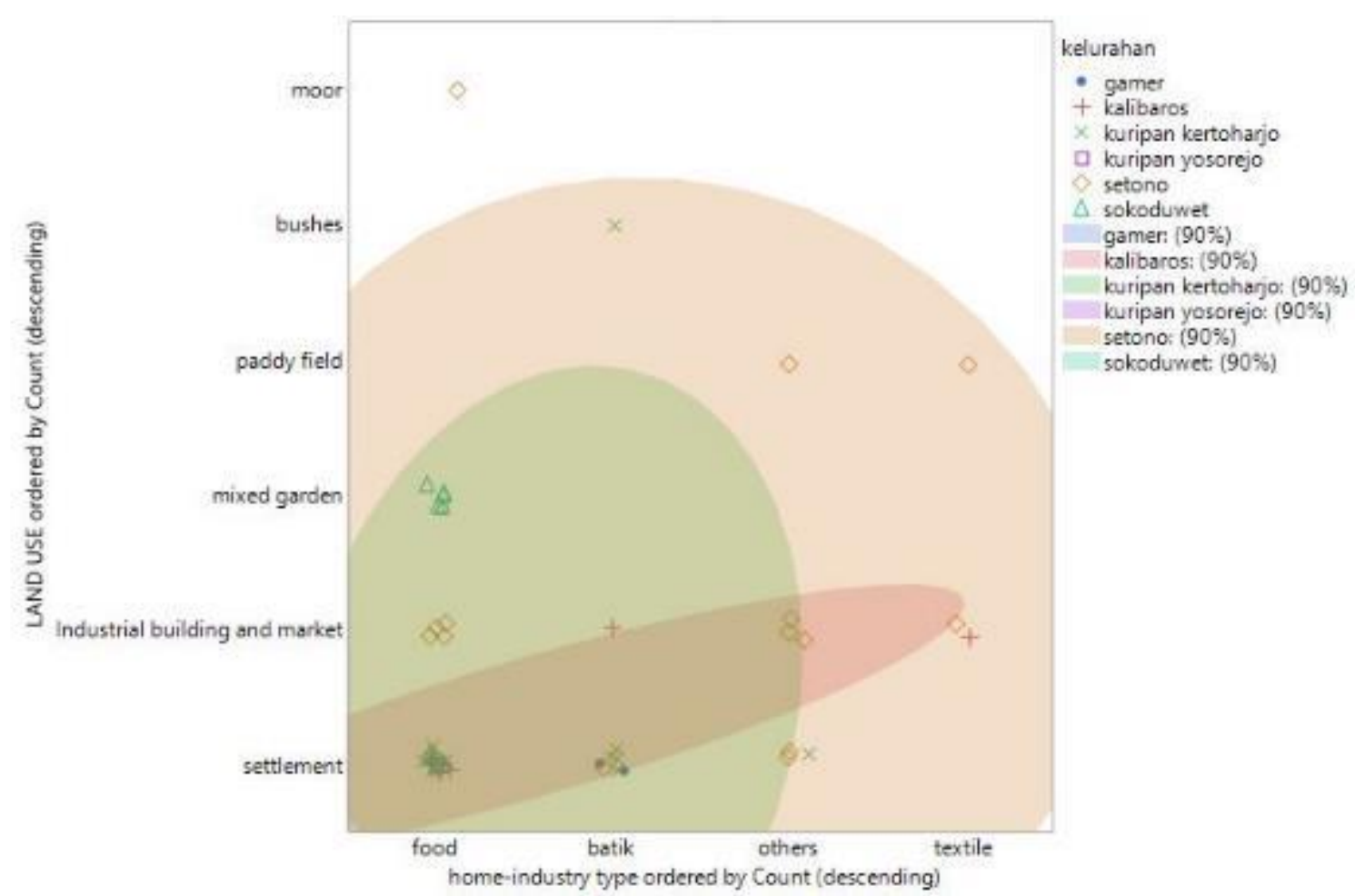

Fig. 4. The proportion of the number of home industries located on Landuse of Industrial Buildings and Market and Non-Industrial Area.

point).

The geolocation points feature of home industries were joined with spatial data of land use of Pekalongan city to identify which land use where home industries were located. It determined that home industries were mainly situated at settlements (Figure 4 and Table 2). The points of home industries were $77,14 \%$ existed in land use of settlement. The home industries were also located in land use of mix-use gardens $(14,29 \%)$, and fewer points of home industries were situated in land use of paddy fields and bushes. The findings of home industries were more found in settlements' land use, considering that the home industry is generally located in territories. However, the most important finding is the home industry location within the settlements where the data is rarely available. In urban planning, of course, it needs to be considered regarding the planning of the development of settlements area. The area of the settlements that have a home industry has a different facility planning from ordinary settlements.

The Geolocation data of home industries can be further analyzed in ArcGIS to overcome more information such as point density and distance to other features. The spatial planning of Kernel density in ArcGIS was implemented to identify the concentration of Geolocation of home industries as consideration to develop facilities for home industries. From the analysis, it identified that the home industries were more concentrated on Kuripan Kertoharjo village (Figure 5). The other concentration appeared in Kalibaros village. The number of home industries in Sokoduwet village was more than Kalibaros village. However, the Geolocation of home industries in Kalibaros village was more spread along the road.

The spatial information of geolocations and concentration of home industries are very important for the decision maker to list the priority of home industries

Table 2. The Land use where the home industries were existed

\begin{tabular}{|c|c|c|c|c|c|}
\hline$\frac{\text { Count }}{\text { Total } \%}$ & bushes & mixed garden & paddy field & settlement & Total \\
\hline \multirow{2}{*}{ batik } & 1 & 0 & 0 & 7 & 8 \\
\hline & 2,86 & 0 & 0 & 20,00 & 22,86 \\
\hline \multirow{2}{*}{ food } & 0 & 5 & 0 & 17 & 22 \\
\hline & 0 & 14,29 & 0 & 48,57 & 63,89 \\
\hline \multirow{2}{*}{ others } & 0 & 0 & 1 & 3 & 4 \\
\hline & 0 & 0 & 2,86 & 8,57 & 11,11 \\
\hline \multirow{2}{*}{ textile } & 0 & 0 & 1 & 0 & 1 \\
\hline & 0 & 0 & 2,86 & 0 & 2,78 \\
\hline \multirow{2}{*}{ Total } & 1 & 5 & 2 & 27 & \multirow{2}{*}{35} \\
\hline & 2,86 & 14,29 & 5,71 & 77,14 & \\
\hline
\end{tabular}




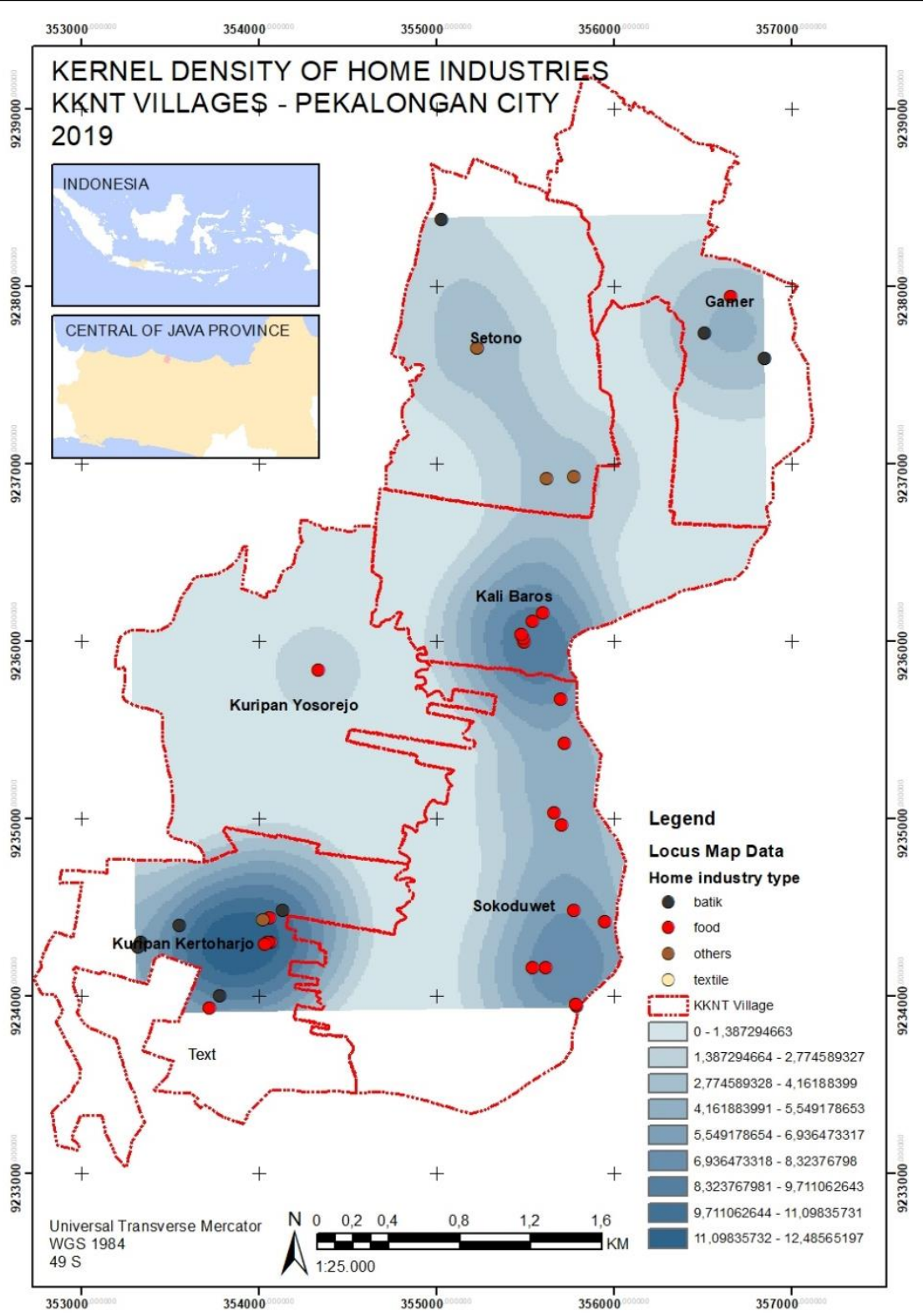

Fig. 5. The Kernel density of The Home Industries of 6 villages

development. The area that more concentrated with home industries was more priority to develop central of the home industry or add more facilities related to improving home industries such as sewage disposal, warehouse, loading spaces, etc.

This paper is not the first to raise the theme of using mobile technology for mapping industrial locations in Indonesia because Agha et al., (2017) and Herlina (2018) has successfully carried out data collection of industrial geo-locations in their respective case studies. However, this paper may be the first to address the geo-location of home industries in the middle of residential areas using mobile technology-based participatory mapping which the data is inputted by a group of students as volunteers.

\section{Discussion and Conclusion}

The implementation of mobile technology-based participatory mapping methods using Locus Map software has been running well in mapping home industries in 6 villages in Pekalongan city. This is supported by the availability of smartphones and internet technology in Pekalongan city. The students, as on-site surveyors have sufficient knowledge in operating the Locus Map software and understanding the instructions.

This will be a challenge to conduct participatory mapping if the on-site surveyors are ordinary people who less knowledge about online mapping and operating smartphones. However, this can be avoided by conducting training to on-site surveyors before the field survey is conducted.

A good internet connection in the Pekalongan city strongly supports the smooth process of taking on-site data and transferring data to researchers. The field survey problem was not in the availability of tools but in terms of survey coverage and mapping capacity that influence participants' motivation. The motivation of each surveyor can affect the quality of data. Perhaps this is the controversy in the validity of the data obtained through this participatory mapping method. In geographic information research involving volunteers, 
the results could be influenced by participants' motivation to the field survey to affect the coverage and validity of the data obtained (Flanagin and Metzger, 2008). For future research, an effort to improve participants' understanding of the data needed and the motivation to carry out surveys is to provide participants incentives (Brown and Kyttä, 2014).

The existence of home industries must be considered because it influences people's income. The planning and development of settlements with and without home industries must be paid attention to the zoning and providing facilities. Therefore, it is important to consider concentration or hotspots where home industries exist most in the zoning. Since the mapping using Locus Map produces points features, it is possible to do point density analysis to identify areas that home industries concentrate most. This participatory mapping method produces data in a good scale so that it can be used as input in regional planning for the Pekalongan city. It is supported (Rall et al., 2019) that participatory GIS can produce data at a good scale so that it is useful in urban planning and management.

The mobile technology-based participatory mapping method can be implemented well in this study to map the Geolocation of home industries in 6 villages in Pekalongan city. Geolocation data from home industries is a form of spatial data taken on-site by participants who live in the town. The geolocation data of home industries are data that are usually presented in the form of nonspatial. The geolocation data from home industries presented in the spatial form can be further analyzed, such as identifying the concentration of home industries' locations using point density and proximity of each home industry to road infrastructure using near analysis. The analysis results can complement non-spatial data from home industries, which is very useful in making urban planning decisions.

The participant's knowledge of the smartphone and the locus map application and adequate tools are the keys to this method's implementation. The selection of participants from students brings benefits for implementing this method because each student as a participant is familiar with mobile technology and is also easy to understand field mapping procedures. However, briefing participants before conducting field surveys and adequate incentives to increase participant motivation is essential for obtaining satisfactory mapping results.

\section{Acknowledgements}

We would like to give our thanks to LPPM IPB and KKNT students of Pekalongan City 2019.

\section{References}

Agha, Z. A., Triwinarko, A., Hamuna, B. (2017). Pemetaan Industri di Kota Batam Menggunakan Mobile GIS Berbasis Android. Journal of Applied Informatics and Computing, 1(1), 1-4, doi:org/ 10.30871/jaic.v1i1.990
Arca, D. , Seker, D. Z. , Alkan, M. , Karakıs, S. , Bayık, C., Acar, H. (2018). Development of Web-Based GIS for the Cultural Heritage of Safranbolu, Turkey. International Journal of Environment and Geoinformatics, 5(3), 368-377, doi.10.30897/ijegeo. 457184

Azyat, A., Raissouni, N., Ben Achhab, N., Lahraoua, M., Chahboun, A. (2012). Mobile Geographic Information System Platform (MGISP): A GPS Information Collection System. International Journal of Information and Network Security (IJINS), 1(2), 140-151, doi.org/10.11591/ijins.v1i2.534

Brown, G., Kyttä, M. (2014). Key issues and research priorities for public participation GIS (PPGIS): A synthesis based on empirical research. Applied Geography, 46, 122-136, doi.org/10.1016/ j.apgeog.2013.11.004

Brown, G., Sanders, S., Reed, P. (2018). Using public participatory mapping to inform general land use planning and zoning. Landscape and Urban Planning, 177(March), 64-74, doi.org/10.1016/ j.landurbplan.2018.04.011

Damayanti, M., Latifah, L. (2015). Strategi Kota Pekalongan Dalam Pengembangan Wisata Kreatif Berbasis Industri Batik. Jurnal Pengembangan Kota, 3(2), 100, doi.org/10.14710/jpk.3.2.100-111

Endarwati, M. C. (2011). Berkenalan Dengan Gis Untuk Aplikasi Perencanaan Kota. Jurnal Sabua, 3(3), 50 55.

Falco, E., Zambrano-Verratti, J., Kleinhans, R. (2019). Web-based participatory mapping in informal settlements: The slums of Caracas, Venezuela. Habitat International, 94(September), 102038, doi.org/10.1016/j.habitatint.2019.102038

Flanagin, A. J., Metzger, M. J. (2008). The credibility of volunteered geographic information. GeoJournal, 72(3-4), 137-148, doi.org/10.1007/s10708-0089188-y

Fornace, K. M., Surendra, H., Abidin, T. R., Reyes, R., Macalinao, M. L. M., Stresman, G., Luchavez, J., Ahmad, R. A., Supargiyono, S., Espino, F., Drakeley, C. J., Cook, J. (2018). Use of mobile technologybased participatory mapping approaches to geolocate health facility attendees for disease surveillance in low resource settings. International Journal of Health Geographics, 17(1), 1-10, doi.org/ 10.1186/s12942-018-0141-0

Gabryszuk, J. (2020). The potential to use smartphonebased gnss receiverfor surveying. Geomatics and Environmental Engineering, 14(2), 49-57, doi.org/10.7494/geom.2020.14.2.49

Gülmez, S., Tuşat, E. (2017). The Analysis of GPS Data in Different Observation Periods Using Online GNSS Process Services. International Journal of Environment and Geoinformatics, 4(1), 43-53, doi.10.30897/ijegeo.306492

Herlina, A. (2018). Mobile Gis Sebaran Pabrik Gula Di Provinsi Jawa Timur. Metik Jurnal, 2(2), 53-57.

Kelly, M., Ferranto, S., Lei, S., Ueda, K. ichi, and Huntsinger, L. (2012). Expanding the table: The web as a tool for participatory adaptive management in California forests. Journal of Environmental 
Management, 109, 1-11, doi.org/10.1016/ j.jenvman.2012.04.035

Kingston, R. P. (2007). Public participation in local policy decision-making: The role of Web-based mapping. Cartographic Journal, 44(2), 138-144, doi.org/10.1179/000870407X213459

Klonner, C., Usón, T. J., Aeschbach, N., Höfle, B. (2021). Participatory Mapping and Visualization of Local Knowledge: An Example from Eberbach, Germany. International Journal of Disaster Risk Science, 12(1), 56-71, doi.org/10.1007/s13753-02000312-8

Korkutan, M. , Doğru, A. Ö., Goksel, C. (2018). Impact Analysis of Sanitary Landfill Based Odour In Istanbul Using GIS, International Journal of Environment and Geoinformatics, 5(2), 169-177, doi.10.30897/ ijegeo.421545.

Korpilo, S., Virtanen, T., Lehvävirta, S. (2017). Smartphone GPS tracking-Inexpensive and efficient data collection on recreational movement. Landscape and Urban Planning, 157, 608-617, doi.org/10.1016/j.landurbplan.2016.08.005

Laituri, M., Kodrich, K. (2008). On line disaster response community: People as sensors of high magnitude disasters using internet GIS. Sensors, 8(5), 3037-3055, doi.org/10.3390/s8053037

Lee, J. (2020). Designing an inquiry-based field work project for students using mobile technology and its effects on students' experience. Review of International Geographical Education Online, 10(SpecialIssue1),

14-39, doi.org/10.33403/rigeo.637666

Nowak, M. M., Dziób, K., Ludwisiak, Ł., Chmiel, J. (2020). Mobile GIS applications for environmental field surveys: A state of the art. Global Ecology and Conservation, 23 , doi.org/10.1016/j.gecco.2020.e01089

Pelly, D. A., Wiyono, M. B. (2020). Participatory Mapping of Village Potential with Geotagging Data (Case Study: Wedomartani Village, Sleman, Yogyakarta). BHUMI: Jurnal Agraria Dan Pertanahan, 5(3), 77-84, doi.org/10.31292/ jb.v5i3.394

Rall, E., Hansen, R., Pauleit, S. (2019). The added value of public participation GIS (PPGIS)for urban green infrastructure planning. Urban Forestry and Urban Greening, 40(June 2018), 264-274, doi.org/10.1016/j.ufug.2018.06.016

Riggs, W., Gordon, K. (2017). How is mobile technology changing city planning? Developing a taxonomy for the future. Environment and Planning B: Urban Analytics and City Science, 44(1), 100119, doi.org/10.1177/0265813515610337

Rukayah, R. S., Wibowo, A. A., Wahyuningrum, S. H. (2015). Public Participation in Branding Road Corridor as Shopping Window or Batik Industry at Pekalongan. Procedia - Social and Behavioral Sciences, 168, 76-86, doi.org/10.1016/j.sbspro.2014.10.212

Rzeszewski, M., Kotus, J. (2019). Usability and usefulness of internet mapping platforms in participatory spatial planning. Applied Geography,
103 (May 2018), 56-69, doi.org/10.1016/ j.apgeog.2019.01.001

Tata, H., Eteje, O. (2022). Determination of Orthometric Heights of Points Using Gravimetric/GPS and Geodetic Levelling Approaches. International Journal of Environment and Geoinformatics, 9(1), 52-59.

Thrall, G. I. (1998). GIS applications in real estate and related industries. Journal of Housing Research, 9(1), 33-59.

Zandbergen, P. A., Barbeau, S. J. (2011). Positional accuracy of assisted GPS data from high-sensitivity GPS-enabled mobile phones. Journal of Navigation, 64(3), 381-399, doi.org/10.1017/ S0373463311000051

Zhou, X., Li, D. (2018). Quantifying multi-dimensional attributes of human activities at various geographic scales based on smartphone tracking. International Journal of Health Geographics, 17(1), 1-13, doi.org/10.1186/s12942-018-0130-3. 